\title{
Persepsi Keluarga terhadap Skizofrenia
}

\author{
Suryani, Maria Komariah, Wiwi Karlin \\ Fakultas Keperawatan Universitas Padjadjaran \\ E-mail:ynsuryani@yahoo.com
}

\begin{abstract}
Abstrak
Keluarga yang memiliki anggota keluarga dengan skizofrenia mengalami isolasi sosial karena stigma yang melekat pada penderita. Oleh karena itu, penderita skizofrenia sering kali disembunyikan dan dikucilkan agar tidak diketahui oleh masyarakat. Padahal persepsi keluarga yang positif sangat dibutuhkan dalam perawatan pasien skizofrenia. Tujuan dari penelitian ini yaitu untuk mengetahui persepsi keluarga terhadap skizofrenia. Penelitian ini menggunakan metode deskriptif kuantitatif. Sampel pada penelitian ini berjumlah 80 responden, yang diambil dengan menggunakan teknik consecutive sampling. Pengumpulan data menggunakan kuesioner persepsi keluarga mengenai skizofrenia yang dikembangkan sendiri oleh peneliti dengan hasil uji reliabilitas sebesar 0.70. Analisis data pada penelitian ini dilakukan dengan menggunakan statistik deskriptif dalam bentuk analisis nilai mean. Hasil penelitian menunjukkan bahwa sebagian besar responden $(62,5 \%)$ memiliki persepsi positif terhadap skizofrenia, sedangkan sisanya sebanyak 30 responden $(37,5 \%)$ memiliki persepsi negatif terhadap skizofrenia. Hal ini menunjukkan masih terdapatnya persepsi keluarga yang negatif terhadap skizofrenia. Salah satu cara yang dapat dilakukan perawat untuk merubah persepsi keluarga tersebut adalah dengan melakukan penyuluhan kepada keluarga tentang skizofrenia. selain itu, rumah sakit jiwa perlu mengembangkan promosi kesehatan di masyarakat agar terciptanya persepsi yang positif terhadap skizofrenia.
\end{abstract}

Kata kunci: Deskriptif kuantitatif, keluarga, persepsi, skizofrenia.

\section{Familie's Perception towards Schizophrenia}

\begin{abstract}
Families who have a family member suffering from schizophrenia experience social isolation related stigma. Therefore, people with schizophrenia often hide and isolated in order to be not known by the public, whereas positive perception of the families towards schizophrenia is needed in the treatment of schizophrenia. The purpose of this study was to determine the perception of the families about schizophrenia. This research used descriptive quantitative method. Samples in this study amounted to 80 respondents using consecutive sampling. The data was collected for one week by using the questionnaire. The reliability test results of the questinnaire obtained for 0.70 . Analysis of the data used descriptive statistical analysis in the from of a mean. The results showed that most of the respondents have a positive perception of schizophrenia by 50 respondents and the remaining 30 respondents had negative perceptions toward schizophrenia. This shows there is still a negative perception of families towards schizophrenia. One of the ways that can be done to change the familie's perception is by giving health education to the families and psychiatric hospitals need to develop health promotion in the community to creat a positive perception towards schizophrenia.
\end{abstract}

Key words: Family, perception, quantitatif study, schizophrenia. 
Suryani: Pensepsi Keluarga terhadap Skizofrenia

\section{Pendahuluan}

Kesehatan jiwa pada saat ini semakin menjadi masalah utama, terutama di negaranegara maju. Walaupun masalah kesehatan jiwa bukan menjadi salah satu masalah penyebab kematian secara langsung, namun masalah kesehatan ini dapat menimbulkan ketidakmampuan seseorang dalam berkarya dan tidak tepat dalam berperilaku sehingga menimbulkan masalah bagi suatu kelompok, termasuk masyarakat (Irmansyah, 2003). Berdasarkan hasil laporan dari World Health Organization (WHO) (2010), penderita gangguan jiwa dengan diagnosis skizofrenia sudah mencapai sekitar 24 juta jiwa di seluruh dunia.

Berdasarkan data Riset Kesehatan Dasar (Riskesdas) tahun 2013, di Indonesia angka gangguan jiwa telah mengalami peningkatan secara signifikan dari 0.5 per mil pada tahun 2007 menjadi 1,7 per mil pada tahun 2013, dari total jumlah penduduk sebanyak 251 juta jiwa. Provinsi Jawa Barat sendiri merupakan salah satu provinsi dengan angka gangguan jiwa tertinggi di Indonesia yang mencapai $20 \%$ dari 45 juta penduduk atau sekitar 9 juta jiwa. Diantara jenis gangguan jiwa yang sering ditemukan, salah satunya adalah skizofrenia (Riskesdas, 2007). Keadaan tersebut di atas didukung dengan didapatkannya data dari rekam medis Rumah Sakit Jiwa (RSJ) Provinsi Jawa Barat. Hasil ini menunjukkan bahwa pada tahun 2013 tercatat 35.986 pasien skizofrenia yang datang berobat ke unit rawat jalan RSJ Provinsi Jawa Barat. Data tersebut menunjukkan prevalensi skizofrenia di wilayah Jawa Barat cenderung memiliki angka yang cukup tinggi. Selain itu, hal ini didukung oleh faktor kekambuhan yang sering muncul pada pasien skizofrenia.

Skizofrenia adalah suatu gangguan psikosa, dengan gangguan utama pada proses berpikir, persepsi, kognisi, dan fungsi sosial (Elder, Evans, \& Nizette, 2005). Halusinasi merupakan suatu gejala yang khas pada skizofrenia (Uhlhass \& Mishara, 2006), yang mana individu tidak dapat membedakan antara stimulasi internal dan eksternal. Individu seolah-olah melihat atau mendengar sesuatu yang pada kenyataannya tidak ada. Menurut hasil penelitian Shawyer, dkk. (2008), individu yang mengalami halusinasi dapat membahayakan bagi dirinya sendiri maupun orang lain, karena halusinasinya terkadang menyuruhnya untuk melakukan kekerasan. Banyak sekali diantara penderita skizofrenia ini yang sudah mendapatkan pengobatan dan mencapai kondisi stabil, tetapi mengalami kekambuhan yang diakibatkan oleh beberapa faktor (Carpenter, 2004).

Pencegahan lebih lanjut dibutuhkan untuk menurunkan angka kekambuhan skizofrenia. Pencegahan tersebut dapat dilakukan dengan dukungan keluarga sebagai upaya perawatan secara langsung sehingga keluarga lebih dapat memahami masalah yang dihadapi oleh pasien gangguan jiwa (Minas \& Diatri, 2008). Dalam hal ini sangat dibutuhkan pendekatan holistik, yaitu manusia harus dipandang sebagai suatu keseluruhan yang paripurna, dan keluarga sebagai faktor lingkungan yang terdekat dengan penderita. Keluarga sangat berperan dalam perawatan dan rehabilitasi anggota keluarga yang menderita skizofrenia (Durand \& Barlow, 2007).

Keluarga yang memiliki anggota keluarga yang menderita skizofrenia, menganggap penderita sebagai aib bagi keluarga dan membuat mereka mengalami isolasi sosial. Oleh karena itu, penderita skizofrenia sering kali disembunyikan dan dikucilkan agar tidak diketahui oleh masyarakat. Hal ini justru akan memberatkan gejala yang dialami pasien, sehingga tentunya juga akan memberatkan bagi keluarga yang merawatnya (Durand \& Barlow, 2007). Kurangnya pengetahuan dari keluarga dalam hal merawat pasien, menjadi faktor utama dalam meningkatnya angka kekambuhan penderita skizofrenia. Beberapa faktor yang dapat memengaruhi pengetahuan, diantaranya: tingkat pendidikan, motivasi, pengalaman, dan persepsi (Pelling, 2008).

Terdapatnya stigma yang buruk dari masyarakat terhadap penderita gangguan jiwa, diantaranya gangguan jiwa merupakan penyakit yang sulit disembuhkan dan aib bagi keluarga (Irmansyah, 2003). Hal ini bukan hanya menimbulkan konsekuensi negatif bagi penderita, tetapi juga dapat menimbulkan persepsi yang negatif bagi keluarga sehingga muncullah sikap penolakan, sikap penyangkalan, disisihkan maupun diisolasi. Karena memiliki anggota keluarga dengan skizofernia bukanlah suatu hal yang mudah. Maka peran keluarga sangat 
Suryani: Pensepsi Keluarga terhadap Skizofrenia

Tabel 1 Distribusi Frekuensi Responden berdasarkan Data Demografi $\mathbf{n = 8 0}$

\begin{tabular}{lcc}
\hline \multicolumn{1}{c}{ Demografi } & Frekuensi $(f)$ & Persentase $(\mathbf{\%})$ \\
\hline Dewasa Dini & 32 & 40 \\
Dewasa Madya & 37 & 46,25 \\
Lanjut Usia & 11 & 13,75 \\
Perempuan & 52 & 65 \\
Laki-laki & 28 & 35 \\
SD & 35 & 43,75 \\
SMP atau SLTP & 14 & 17,5 \\
SMA atau SLTA & 21 & 26,25 \\
Perguruan Tinggi & 4 & 5 \\
Tidak Sekolah & 6 & 7,5 \\
Orangtua & 36 & 45 \\
Kakak atau Adik & 25 & 31,25 \\
Suami atau Istri & 8 & 10 \\
Anak & 11 & 13,75 \\
\hline
\end{tabular}

dibutuhkan dalam proses penyembuhan pasien skizofrenia. Stigma yang muncul di dalam keluarga merupakan suatu masalah bagi keluarga (Irmansyah, 2003).

Persepsi merupakan proses diterimanya rangsangan melalui pancaindera sehingga individu mampu mengetahui, mengartikan, dan menghayati tentang sesuatu yang diamati, baik yang berasal dari dalam maupun dari luar diri individu (Pelling, 2008 \& Sunaryo, 2004). Persepsi keluarga terhadap anggota keluarga yang mengalami skizofrenia merupakan salah satu faktor dalam mendukung kesembuhan pasien.

Keluarga pasien juga sudah seharusnya dapat mengurangi persepsi yang negatif dan diskriminasi terhadap penderita gangguan jiwa dalam keluarga serta dapat memberikan dukungan sosial agar penderita nyaman dengan lingkungannya. Hal tersebut dapat diwujudkan dengan memberikan dukungan sosial kepadanya, meningkatkan rasa empati, penerimaan, mendorong untuk memulai berinteraksi sosial, dan dorongan untuk tidak berputus asa serta terus berusaha. Terapi dukungan sosial ini akan sangat membantu penderita gangguan jiwa dalam menghadapi peristiwa-peristiwa yang menjadi stressor dalam kehidupannya (Nash, 2005).

Hasil dari studi pendahuluan yang telah dilakukan di RSJ Provinsi Jawa Barat, maka didapatkan data tercatat 35.986 dari jumlah seluruh pasien rawat jalan pada tahun 2013. Data tersebut terdiri dari skizofrenia residual 12.116 orang pasien, hebrefenik 7.849 orang pasien, paranoid 4.110 orang pasien, katatoni 82 orang pasien, dan terdapat 9.160 orang gangguan jiwa lainnya hingga tidak terinci sebanyak 249 orang pasien.

Dari hasil wawancara yang dilakukan terhadap enam orang anggota keluarga yang sedang mengantar anggota keluarga berobat, menunjukkan hasil bahwa sebanyak empat orang anggota keluarga menyatakan tidak suka, bingung, dan malu mempunyai anggota keluarga yang mengalami gangguan jiwa dan tidak mampu merawat pasien selama ini disebabkan oleh kondisi pasien yang aneh. Keluarga menganggap bahwa apabila pasien sedang kambuh, berarti setan atau

Tabel 2 Distribusi Frekuensi Persepsi Keluarga terhadap Skizofrenia $(n=80)$

\begin{tabular}{lccc}
\hline & Kategori & Frekuensi $(f)$ & Persentase $(\%)$ \\
\hline Positif & 50 & 62,5 \\
Negatif & 30 & 37,5 \\
\hline
\end{tabular}


Suryani: Pensepsi Keluarga terhadap Skizofrenia

Tabel 3 Kategori Persepsi Keluarga terhadap Pengertian Skizofrenia

\begin{tabular}{lccc}
\hline & Kategori & Frekuensi $(f)$ & Persentase (\%) \\
\hline Positif & 41 & 51,3 \\
Negatif & 39 & 48,8 \\
\hline
\end{tabular}

roh halus sedang masuk ke dalam tubuhnya. Mereka memersepsikan bahwa penderita gangguan jiwa adalah sebuah penyakit yang memalukan bagi keluarga dan ketidaktahuan keluarga dalam bertindak pada anggota keluarganya yang sedang sakit. Keluarga pun merasa tidak nyaman dengan kondisi salah satu keluarganya yang seperti itu, di sisi lain mereka pun harus bisa melakukan suatu tindakan agar saudara, istri, maupun anaknya yang sedang sakit tersebut dapat sembuh kembali. Terdapat beberapa dari mereka merasa malu terhadap anggapan negatif dari tetangga sekitar tentang anggota keluarganya yang mengalami skizofrenia. Oleh karena itu, hal ini penting untuk diteliti. Berdasarkan latar belakang yang telah diuraikan tersebut, peneliti sangat tertarik melakukan penelitian yang bertujuan untuk mengetahui persepsi keluarga terhadap skizofrenia.

\section{Metode Penelitian}

Jenis penelitian ini yaitu penelitian deskriptif kuantitatif. Populasi pada penelitian ini adalah keluarga dengan anggota keluarga yang mengalami skizofrenia yang berobat di Unit Rawat Jalan RSJ Provinsi Jawa Barat dalam kurun waktu bulan Oktober-Desember 2013, sehingga didapatkan sebanyak 6.005 pasien dengan rata-rata jumlah kunjungan adalah 2.002 pasien perbulan.

Sampel diambil dengan teknik consecutive sampling, yaitu dengan mencari penderita yang memenuhi kriteria inklusi dan ekslusi sampai terpenuhi jumlah dari sampel yang diperlukan. Kriteria sampel yang diambil harus dapat mewakili karekteristik populasi yang telah dikenal sebelumnya. Kriteria inklusi pada penelitian ini, meliputi: anggota keluarga sudah memasuki usia dewasa; anggota keluarga inti dari pasien skizofrenia yang meliputi ayah, ibu, suami atau istri, saudara (kakak atau adik), atau anak; dan anggota keluarga yang bertanggung jawab dalam merawat pasien di rumah. Kriteria ekslusi, meliputi: anggota keluarga yang menolak menjadi responden dan tidak menyelesaikan pengisian kuesioner. Jumlah sampel pada penelitian ini adalah sebanyak 80 keluarga.

Instrumen untuk pengumpulan data pada penelitian ini menggunakan angket atau kuesioner yang telah dilakukan uji validitas dan reliabilitas terlebih dahulu, dengan hasil uji reliabilitas 0.70. Domain pada kuesioner ini antara lain mengenai persepsi keluarga terhadap pengertian skizofrenia, persepsi keluarga tentang penyebab skizofrenia, tanda dan gejala, perawatan, dan pengobatan skizofrenia. Persepsi yang dimaksud pada penelitian ini adalah pendapat dari keluarga tentang skizofrenia. Domain yang dikembangkan peneliti pada kuesioner ini, mengacu pada teori dan konsep mengenai skizofrenia dari berbagai sumber yang berasal dari Sadock dan Sadock (2007), Videbeck (2008), dan Suryani, Welch, dan Cox (2013).

Sebelum dilakukan penelitian, terlebih dahulu dilakukan pengurusan uji etik dan izin penelitian. Setelah diperoleh izin etik dan izin penelitian, barulah dilakukan pengumpulan data. Sebelum dilakukan pengumpulan data,

Tabel 4 Kategori Persepsi Keluarga terhadap Penyebab, Tanda dan Gejala Skizofrenia

\begin{tabular}{lcccc}
\hline \multirow{2}{*}{ Kategori } & \multicolumn{2}{c}{ Penyebab Skizofrenia } & \multicolumn{2}{c}{$\begin{array}{c}\text { Tanda dan Gejala } \\
\text { Skizofrenia }\end{array}$} \\
\cline { 2 - 5 } & Frekuensi $(f)$ & Persentase (\%) & Frekuensi $(f)$ & Persentase (\%) \\
\hline Positif & 53 & 66,3 & 47 & 58,8 \\
Negatif & 27 & 33,8 & 33 & 41,3 \\
\hline
\end{tabular}


Suryani: Pensepsi Keluarga terhadap Skizofrenia

Tabel 5 Kategori Persepsi Keluarga terhadap Perawatan Skizofrenia

\begin{tabular}{lccc}
\hline & Kategori & Frekuensi $(f)$ & Persentase $(\%)$ \\
\hline Positif & 41 & 51,3 \\
Negatif & 39 & 48,8 \\
\hline
\end{tabular}

terlebih dahulu informan diberikan informed consent oleh peneliti.

Analisis data pada penelitian ini dilakukan dengan cara menghitung nilai mean dari tiap jawaban responden terhadap pernyataan dalam kuesioner. Persepsi responden pada penelitian ini diukur dengan menggunakan menggunakan skala likert yaitu pernyataan positif atau mendukung (favorable) dan pernyataan negatif atau tidak mendukung (unfavorable), lalu dihitung nilai persentasenya.

\section{Hasil Penelitian}

Karekteristik responden dari 80 orang responden pada penelitian ini disajikan dalam bentuk daftar distribusi frekuensi pada tabel 1. Tabel 1 menunjukkan bahwa sebagian besar responden berada pada usia dewasa madya, yaitu sebanyak 37 orang responden $(46,25 \%)$, sedangkan sebagian kecil dari responden berada pada usia lanjut usia sebanyak 11 orang responden $(13,75 \%)$. Berdasarkan jenis kelamin, didapatkan responden perempuan lebih banyak dibandingkan responden lakilaki, yaitu sebanyak 52 responden perempuan $(65 \%)$, sedangkan sisanya yaitu sebanyak 28 responden $(35 \%)$ dengan jenis kelamin laki-laki. Berdasarkan tingkat pendidikan, menunjukkan bahwa lebih banyak responden dengan tingkat pendidikan sekolah dasar (SD) yaitu sebanyak 35 responden $(43,75 \%)$, berikutnya adalah responden dengan tingkat pendidikan sekolah menengah atas (SMA) atau sekolah lanjut tingkat atas (SLTA) yaitu sebanyak 21 responden $(26,25 \%)$ dan berdasarkan hubungan dengan pasien hampir setengahnya responden adalah orangtua dari pasien yaitu sebanyak 36 responden $(45 \%)$.

Persepsi keluarga terhadap skizofrenia dapat dikategorikan menjadi dua kategori yaitu persepsi yang positif dan persepsi yang negatif. Persepsi keluarga dikategorikan kedalam nilai mean pada variabel persepsi keluarga terhadap skizofrenia yang dinilai berdasarkan indikator, yang terdiri dari: pengertian, penyebab, tanda dan gejala, perawatan, dan pengobatan.

Kategori persepsi keluarga terhadap skizofrenia dapat dilihat pada tabel 2. Pada tabel 2 dapat terlihat bahwa persepsi keluarga terhadap skizofrenia menunjukkan sebagian besar responden termasuk kedalam kategori positif yaitu sebanyak 50 orang responden $(62,5 \%)$, sedangkan sisanya termasuk kategori negatif yaitu sebanyak 30 orang responden $(37,5 \%)$. Dengan demikian, maka sebagian besar responden keluarga memiliki persepsi yang positif terhadap skizofrenia.

Persepsi keluarga terhadap skizofrenia dapat dilihat berdasarkan dimensi pengertian, penyebab, tanda dan gejala, perawatan, dan pengobatan. Kategori pada masingmasing dimensi persepsi keluarga terhadap skizofrenia dapat dilihat pada tabel 3,4, 5, dan 6.

Pada tabel 3, persepsi responden terhadap pengertian dari skizofrenia, menunjukkan hasil bahwa hampir seimbang antara yang memiliki persepsi positif dan negatif, hanya dibedakan dengan dua orang reponden. Keluarga yang memiliki persepsi positif yaitu sebanyak 41 orang $(51,3 \%)$, sedangkan sisanya termasuk kategori negatif yaitu sebanyak 39 orang $(48,8 \%)$.

Tabel 4 menunjukkan bahwa responden

Tabel 6 Kategori Persepsi Keluarga terhadap Pengobatan Skizofrenia

\begin{tabular}{lccc}
\hline & Kategori & Frekuensi $(f)$ & Persentase $(\%)$ \\
\hline Positif & 71 & 88,8 \\
Negatif & 9 & 1,3 \\
\hline
\end{tabular}


yang memiliki persepsi positif lebih banyak jika dibandingkan dengan responden yang memiliki persepsi negatif dengan hasil sebanyak 53 orang responden (66,3\% memiliki persepsi yang positif dan sisanya sebanyak 27 orang $(33,8 \%)$ memiliki persepsi yang negatif. Persepsi responden terhadap tanda dan gejala lebih banyak responden yang memiliki persepsi positif, walaupun hasil responden yang memiliki persepsi negatif juga cukup banyak, dengan hasil sebanyak 47 orang $(58,8 \%)$ memiliki persepsi yang positif dan disusul dengan responden yang memiliki persepsi negatif sebanyak 33 orang (41,3\%). Dengan demikian, maka dapat disimpulkan sebagian besar responden keluarga memiliki persepsi yang positif terhadap penyebab, serta tanda dan gejala skizofrenia.

Pada tabel 5, persepsi responden terhadap perawatan skizofrenia, menunjukkan hasil yang hampir seimbang antara yang memiliki persepsi positif dan negatif, hanya dibedakan dengan dua reponden. Keluarga yang memiliki persepsi positif yaitu sebanyak 41 orang $(51,3 \%)$, sedangkan sisanya termasuk kategori negatif yaitu sebanyak 39 orang $(48,8 \%)$.

Tabel 6 menunjukkan persepsi responden terhadap pengobatan skizofrenia pada kategori positif yang memiliki hasil yang sangat jauh berbeda dengan kategori responden dengan kategori negatif, dengan hasil sebanyak 71 orang $(88,8 \%)$ memiliki persepsi yang positif, dan sisanya sebanyak 9 orang $(11,3 \%)$ memiliki persepsi yang negatif. Dengan demikian, maka dapat disimpulkan, bahwa sebagian besar responden memiliki persepsi yang positif terhadap pengobatan skizofrenia.

\section{Pembahasan}

Persepsi keluarga terhadap anggota keluarga yang mengalami skizofrenia merupakan salah satu faktor dalam mendukung kesembuhan pasien. Keluarga sudah seharusnya dapat mengurangi persepsi negatif dan diskriminasi terhadap penderita gangguan jiwa dalam keluarga dan memberikan dukungan sosial kepadanya, rasa empati, sikap penerimaan, mendorong untuk mulai berinteraksi sosial, dan dorongan untuk tidak berputus asa dan terus berusaha (Nash, 2005).

Hasil penelitian menunjukkan bahwa dari 80 responden, tedapat sebanyak 50 responden $(62,5 \%)$, dan sisanya memiliki persepsi yang negatif sebanyak 30 responden $(37,5 \%)$. Dari data ini dapat diinterpretasikan bahwa sebagian besar responden memiliki persepsi yang positif terhadap skizofrenia, namun belum seluruhnya dari responden memiliki persepsi yang positif terhadap skizofrenia. Hal ini tentunya perlu mendapatkan perhatian perawat.

Hasil persepsi keluarga yang positif didukung oleh data demografi, yaitu hampir setengahnya dari responden dengan rentang usia 18-40 tahun atau dapat disebut dengan masa dewasa madya. Pada usia ini seseorang telah memiliki pengalaman yang cukup baik dalam pendidikan maupun dalam pergaulan, sehingga mereka sudah memiliki sikap yang pasti dan sudah memiliki nilai-nilai hubungan sosial yang berkembang dengan baik (Filip \& Zdenek, 2011). Hal ini akan memengaruhi persepsi keluarga pasien terhadap pengertian, penyebab, tanda dan gejala, perawatan, dan pengobatan terhadap pasien skizofrenia.

Persepsipositifkeluargakemungkinanjuga didukung oleh keluarga yang berobat secara rutin ke rumah sakit, sehingga memperoleh informasi yang cukup tentang skizofrenia dan pengobatan serta perawatannya. Sedangkan keluarga yang masih memiliki persepsi negatif, kemungkinan karena kurangnya kunjungan keluarga dalam berobat ke rumah sakit, karena keluarga menganggap apabila obat sudah habis dan pasien tenang kembali berarti pasien telah sembuh dan tidak perlu dibawa berobat ke rumah sakit lagi. Dalam merawat pasien dengan skizofrenia, bukan saja dibutuhkan obat, namun dibutuhkan juga pendekatan holistik. Pada pendekatan ini, manusia harus dipandang sebagai suatu keseluruhan yang paripurna, dan keluarga sebagai faktor lingkungan yang terdekat dengan penderita. Keluarga sangat berperan dalam perawatan dan rehabilitasi anggota keluarga yang menderita skizofrenia (Durand \& Barlow, 2007).

Secara keseluruhan, responden memiliki persepsi yang positif. Apabila dilihat dari data per subvariabel, didapatkan bahwa persepsi 
keluarga terhadap pengobatan skizofrenia menunjukkan hasil bahwa sebanyak 71 orang responden $(88,8 \%)$ memiliki persepsi yang positif. Data subvariabel yang lainnya, seperti persepsi terhadap penyebab dan tanda gejala sama-sama memiliki persepsi yang positif, dengan persentase kategori positif lebih besar daripada negatif yaitu sebesar $66,3 \%$ dan 58,8\%. Selanjutnya didapatkan data persepsi terhadap pengertian dan persepsi terhadap perawatan, akan tetapi data berikut ini menunjukkan bahwa persepsi terhadap pengertian maupun persepsi terhadap perawatan sama-sama menunjukkan hasil yang seimbang antara persepsi positif dan negatif, yaitu sebesar $51,3 \%$ responden memilki pesepsi positif dan sisanya $48,8 \%$ responden memilki persepsi negatif.

Dari data tersebut dapat diartikan bahwa sebagian besar responden sudah memiliki persepsi yang positif terhadap skizofrenia, walaupun belum seluruhnya. Seperti yang terlihat pada hasil persentase persepsi keluarga terhadap pengertian dan perawatan yang hampir setengahnya dari responden memiliki persepsi yang negatif, artinya bahwa masih banyak responden yang belum paham ataupun mengerti tentang penyakit skizofrenia maupun tentang perawatan langsung terhadap pasien dengan skizofrenia tersebut. Berdasarkan Sadock dan Sadock (2007), pengetahuan keluarga sangatlah penting bagi penderita skizofrenia, karena dengan pengetahuan keluarga dapat membantu untuk meningkatkan fungsi sosial dan kognitif pasien. Pengetahuan yang dimiliki keluarga, memungkinkan keluarga dapat menghilangkan stigma-stigma yang kurang baik terhadap pasien, sehingga keluarga tidak memiliki keyakinan yang salah pada penderita skizofrenia. Selain itu, pasien membutuhkan perhatian dan perawatan yang komprehensif dan berkelanjutan dari keluarga dalam jangka waktu yang sangat lama agar kondisi pasein skizofrenia tetap stabil (Frisch \& Frisch, 2006).

Begitu pula dengan hasil persentase persepsi keluarga terhadap perawatan yang sangat berbeda dengan hasil persentase persepsi terhadap pengobatan, yang menunjukkan bahwa persepsi terhadap perawatan sebanyak $51,3 \%$ dan persepsi terhadap pengobatan sebanyak $88,8 \%$, walaupun sama-sama memiliki hasil dengan kategori positif. Sebanyak 48,8\% responden masih memiliki persepsi yang negatif. Hasil ini menunjukkan bahwa hampir setengahnya dari responden memiliki persepsi negatif terhadap perawatan, kemungkinan mereka masih belum merawat pasien dengan baik, sehingga keluarga masih mengandalkan pengobatan medis saja untuk kesembuhan pasien skizofrenia. Berdasarkan teori Durand dan Barlow (2007), dibutuhkan pendekatan holistik yaitu manusia harus dipandang sebagai suatu keseluruhan yang paripurna dan keluarga sebagai faktor lingkungan yang terdekat dengan penderita. Keluarga sangat berperan dalam perawatan dan rehabilitasi anggota keluarga yang menderita skizofrenia. Selain itu, keluarga juga merupakan pendukung utama dalam memberikan perawatan pada pasien skizofrenia. Oleh karena itu keluarga disini bukan saja hanya untuk memulihkan keadaan pasien seperti semula, tetapi juga bertujuan untuk mengembangkan dan meningkatkan kemampuan keluarga dalam mengatasi masalah kesehatan jiwa di dalam keluarga.

Data berikutnya didapatkan hasil dari persepsi keluarga terhadap tanda dan gejala, yang menunjukkan bahwa sebagian besar dari responden sudah memiliki persepsi yang positif sebanyak 58,8\%, sedangkan hampir setengahnya dari responden masih memiliki persepsi yang negatif sebanyak $41,3 \%$. Persepsi keluarga yang masih negatif tentang tanda dan gejala skizofrenia menunjukkan bahwa keluarga tidak mengetahui secara jelas tanda dan gejala yang muncul pada pasien skizofrenia. Pada saat keluarga memahami tanda dan gejala pada pasien skizofrenia, diharapkan keluarga dapat mengontrol gejala-gejala yang muncul pada pasien skizofrenia, baik itu gejala positif atau negatif. Ketidaktahuan keluarga mengenai tanda dan gejala skizofrenia tidak menjadikan penghambat munculnya gejala pada pasien selama kehidupan pasien seharihari (Videbeck, 2008). Apabila keluarga lebih mengenal masalah serta mengenal tanda dan gejala secara dini, maka keluarga akan dapat mengontrol kondisi pasien tersebut.

Persepsi keluarga yang masih kurang 
favorable terhadap perawatan pasien dan pandangan keluarga yang memandang bahwa obat sebagai satu-satunya terapi untuk kesembuhan pasien, membuktikan bahwa selama ini perawat belum secara terus-menerus mensosialisasikan akan pentingnya perawatan dan bukan hanya pengobatan bagi pasien. Dengan demikian, maka untuk melakukan promosi kesehatan kepada keluarga dalam memberikan asuhan keperawatan kepada pasien maupun keluarga yang merawat, perawat harus mampu memberikan pengetahuan kepada keluarga mengenai cara-cara merawat pasien di rumah, karena keluarga sangat berperan dalam merawat dan meningkatkan keyakinan pasien dalam kesembuhan dirinya dari penyakit skizofrenia (Jenkins, Garcia, Chang, Young, \& Lopez, 2006).

Perawat mungkin dapat melakukan penyuluhan kepada keluarga tentang cara merawat pasien ketika keluarga berkunjung ke RSJ. Akan tetapi, mungkin akan lebih baik apabila keluarga melakukan penyuluhan tersebut dengan melakukan home visite. Pada saat home visite, perawat dapat melihat secara langsung kondisi dan situasi keluarga yang dapat memengaruhi persepsi keluarga terhadap pasien dengan skizofrenia.

\section{Simpulan}

Berdasarkan hasil penelitian yang telah dilakukan, dapat disimpulkan bahwa pada umumnya keluarga mempunyai persepsi yang positif terhadap skizofrenia. Hal ini menunjukkan adanya kecenderungan keluarga akan berperilaku positif dalam merawat klien. Akan tetapi, masih terdapat beberapa responden yang memiliki persepsi negatif terhadap skizofrenia. Hal ini tentunya perlu mendapatkan perhatian dari tenaga kesehatan terutama perawat. Namun, apabila dilihat dari persepsi berdasarkan subvariabel menunjukkan bahwa keluarga memiliki persentase positif yang berbeda-beda, dengan angka tertinggi dimiliki oleh persepsi positif terhadap pengobatan, sedangkan angka terendah pada pengertian dan persepsi terhadap perawatan skizofrenia.

Hasil penelitian ini menunjukkan bahwa persepsi keluarga pasien terhadap pengertian dan perawatan skizofrenia masih kurang favorable dibandingkan dengan persepsi keluarga terhadap pengobatan skizofrenia. Oleh sebab itu, diperlukan penyuluhan yang lebih terinci dan intensif tentang pengertian dan cara perawatan skizofrenia, tidak hanya tentang pengobatan nya saja.

\section{Daftar Pustaka}

Badan Penelitian dan Pengembangan Kesehatan. (2007). Riset Kesehatan Dasar (Riskesda). Jakarta: Kementerian Kesehatan Republik Indonesia.

Carpenter, T. (2004). Clinical Constructs and therapeutic discovery. Schizophrenia Research, 72, 69-73.

Durand, V. M. \& Barlow, D. H. (2007). Essentials of abnormal psychology. Yogyakarta: Pustaka Pelajar.

Elder, R., Evans, K., \& Nizette, D. (2005). Psychiatric and Mental Health Nursing (2nd Ed.). New Zealand: Elseiver.

Filip, C. \& Zdenek, K. (2011). Perception of the situation in the arctic by key actors and the possibility of conflict escalation. Defence Strategy, 5-21.

Frisch, N. C. \& Frisch, L. (2006). Psychiatric mental health nursing. (3rd Ed.). Canada: Thompson Delmar Learning.

Irmansyah. (2003). Harga sebuah ketidakpedulian. Tempo Magazine, 40(32).

Jenkins, J. H., Garcia. J. I. R., Chang, C. L., Young, J. S., \& Lopez, S. R. (2006). Family support predicts psichiatric medication usage among Mexican American individuals with schizophrenia. Social Psyciatry and Psychiatric Epidemology, 41, 624-631.

Minas, H. \& Diatri, H. (2008). Pasung: Physical restraint and confinement of the mental in the community. International Journal of Mental Health System, 2(8), 1-6. 
Nash, J. F. 2005. Penerimaan keluarga skizofrenia. Diakses dari http://72.14.235.104/ search.

Pelling, C. (2008). Concepts, attention, and perception. Philosophical Papers, 37(2), 213-242.

Sadock, B. J. \& Sadock, V. A. (2007). Kaplan \& Sadock's synopsis of psychiatry behavior sciences/ clinical psychiatry (10th Ed.). Lippincott Williams \& Wilkins.

Shawyer, F., Mackinnon A., Farhall J., Sims E., Blaney S., Yardley P., Daly M., Mullen P., \& Colopov D. (2008). Acting on harmful command hallucinations in psychotic disorders. The Journal of Nervous and Mental Disease, 196(5), 390-398.
Sunaryo. (2004). Psikologi untuk keperawatan. Jakarta: EGC

Suryani, Welch, \& Cox. (2013). The phenomena of auditory hallucination as described by Indonesian people living with schizophrenia. Archive of Psychiatric nursing, 27(6), 312-318.

Uhlhass, P. J. \& Mishara, A. L. (2006). Perseptual anomalies in schizophrenia: Integrating phenomenology and cognitive neuroscience. Schizophrenia Bulletin, 33(1).

Videbeck, S. L. (2008). Buku ajar keperawatan jiwa. Jakarta: EGC

World Health Organization. (2010). The world health organization report 2010. 